\title{
THE EFFECT OF HEPARIN ON THE EARLY STAGES OF BLOOD COAGULATION
}

\author{
BY \\ J. R. O'BRIEN \\ From the Central Laboratory, Milton Road, Portsmouth
}

(RECEIVED FOR PUBLICATION MARCH 9, 1959)

From experiments reported it is concluded that heparin combines with and inactivates Christmas factor (C.F.) to form reversibly a heparin-C.F. complex. Apart from the effect of heparin on C.F. and on thrombin, heparin in moderate concentrations was not shown to inactivate any other coagulation factors.

"Available" heparin is defined as heparin in such a state that it can delay some clotting systems. Heparin was rendered " unavailable" or inactive by plasma C.F. and especially by serum C.F., by platelet protein (but not intact platelets), and by platelet-like activity of serum (P.L.A.S.). These three proteins uniquely among all the plasma and serum proteins inactivate heparin.

If an appropriate concentration of heparin is added to whole blood the clotting time is prolonged, due presumably to the inactivation of C.F. by heparin: "available" heparin disappears during clotting and none is found in the serum. The interactions summarized above probably account for these findings. The disappearance of available heparin would also account for the normal thrombin generation and prothrombin consumption observed when heparinized blood clots.

Some properties of P.L.A.S. are reported and its possible role in normal coagulation is considered. Heparin is known to become attached preferentially to one protein rather than another. Some plasma and serum fractions can be arranged in order of their increasing affinity for heparin thus : $\beta$ Lipoproteins $<$ thrombin clotting system $<$ C.F. $<$ platelet protein $<$ protamine sulphate.

Heparin is used extensively in clinical medicine. Mast cells contain heparin, and these cells have been described in the subendothelial layers of the blood vessels (McGovern, 1955): thus heparin may have some physiological anticoagulant role. Precise knowledge of its anticoagulant action may therefore be of practical importance. The antithrombic action of heparin has long been known, but its action on the earlier stages of coagulation is less clear (e.g., Walton, 1955). Biggs, Douglas, and Macfarlane (1953) showed that heparin depresses intrinsic thromboplastin formation. Douglas (1956) suggested that heparin inhibits clotting early in the coagulation process. O'Brien (1958a) claimed that heparin inactivated Christmas factor (C.F.). Shanberge, Barlas, and Regan (1958) claim that the heparin antagonist, protamine sulphate, also inactivates C.F., although Hougie (1958) does not agree. The antiheparin activity of platelets was reported by van Creveld and Paulssen (1951). Garrett and Klein (1957) showed that lipid-extracted platelet material, presumably a protein, contains the antiheparin activity, while the lipid extract contains the clot-accelerating lipid of platelets.

\begin{abstract}
Methods
Native Platelet-rich Plasma.-This was prepared by taking venous blood by syringe and centrifuging $5 \mathrm{ml}$. lots at 500 r.p.m. for five minutes and collecting the supernatant. This was used at once or stored on ice. Silicone-coated apparatus was used throughout.
\end{abstract}

Native Platelet-poor Plasma.-This was prepared by centrifuging native blood at 4,000 r.p.m. for seven minutes and removing two-thirds of the plasma and re-centrifuging this. Silicone-coated apparatus was used throughout.

Citrated Plasma.-This, platelet-rich or plateletpoor, was prepared as above, but the blood was first mixed with one-tenth of its volume of $3.8 \%$ trisodium citrate solution in water.

Normal Serum.-Normal serum was prepared from normal blood by allowing it to clot in contact with glass for at least one hour and centrifuging at 4,000 r.p.m. for 10 minutes and collecting the supernatant.

Platelet-poor Serum.-This was prepared from native platelet-poor plasma by allowing it to clot in contact with glass, centrifuging, and collecting the supernatant.

Absorbed Plasma.-This was prepared by adding to plasma a tenth of a volume of aluminium hydroxide 
gel of such a strength that, after five minutes' incubating and removal of the aluminium hydroxide by centrifugation, the plasma was suitable for the thromboplastin generation test, i.e., the " prothrombin time" was 1-4 minutes. This procedure removes C.F. and some other proteins.

Absorbed Serum.-Absorbed serum was similarly prepared from normal serum.

Cephalin Suspension.-A cephalin suspension was made by suspending $1 \mathrm{mg}$. of asolectin in $1 \mathrm{ml}$. of water or saline.

Heparin.-This was " pularin " brand appropriately diluted with saline; its strength is recorded in units where $100 \mathrm{u}$. is equivalent to $1 \mathrm{mg}$. of heparin.

Thrombin.-Lyophilized human thrombin prepared by the Lister Institute was dissolved in saline so that $1 \mathrm{ml}$. contained 5 units of thrombin. A weak thrombin solution contained 1 unit per $\mathrm{ml}$.

Fibrinogen.-Ampoules of lyophilized human fibrinogen prepared by the Lister Institute contained $1.37 \mathrm{mg}$. of protein. This was dissolved in $1 \mathrm{ml}$. of water and $5 \mathrm{ml}$. of saline for use in the thrombin clotting test, and in $50 \mathrm{ml}$. of saline for the thrombin generation test.

\section{Tests for "Available" Heparin}

Lengthening of Plasma Clotting Time.-The recalcification clotting time of platelet-poor citrated plasma in the presence of powdered glass was measured. If a mixture containing heparin added to this plasma delays the clotting time, available heparin is present.

Lengthening of Thrombin Clotting Time.-Heparin co-factor is present in all the plasma and serum fractions used. One volume of the plasma under investigation to which heparin had been added and one volume of fibrinogen were mixed and allowed to warm in a $37^{\circ} \mathrm{C}$. water-bath for one minute. One volume of a strong thrombin was added and the clotting time was determined. If this clotting time was longer than that when plasma alone was substituted for the heparinized plasma, then available heparin was present. The degree of lengthening of the clotting time was related to the amount of heparin present. This system was found to be very sensitive to calcium ion concentration.

Ability to Inactivate Heparin.-The relative ability of two plasmas to inactivate heparin was compared by adding a similar critical quantity of heparin to both plasmas. How much of the added heparin remained " available" was estimated by carrying out thrombin clotting tests. The plasma giving the longer thrombin clotting time still contained more "available" heparin and therefore had inactivated less.

\section{Tests for Christmas Factor Activity}

The usual test was the thromboplastin generation test (Biggs and Douglas, 1953) in which normal dilute absorbed plasma and cephalin or platelets were used and the test serum diluted 1 in 10 was added.

In some situations the shortening of the clotting time of plasma from a patient suffering from Christmas disease was used.

\section{Tests for Platelet-like Activity of Serum}

The test for this activity, reported in 1955 (O'Brien), was copied exactly. Equal volumes of the serum under investigation and of normal citrated plateletpoor plasma are mixed and placed in a water-bath at $37^{\circ} \mathrm{C}$. for one minute and then recalcified. This tube is watched till it clots, and thereafter $0.1 \mathrm{ml}$. aliquots are transferred at minute intervals to a series of tubes containing $0.4 \mathrm{ml}$. of fibrinogen solution. The clotting time of fibrinogen measures the concentration of thrombin in the original mixture at the time the subsample was taken. The shortest fibrinogen clotting time, measuring the maximum thrombin concentration, is directly related to the P.L.A.S. content of the serum.

Tests for Cephalin Activity of Platelets.-(a) The thrombin generation test was carried out exactly as in the estimation of P.L.A.S., but with the substitution of the platelets under investigation for the serum.

(b) The Stypven time of platelet-poor plasma is greatly accelerated by the addition of isolated cephalins or by cephalin bound in a macromolecule such as platelet protein (O'Brien, 1958b). Equal volumes of plasma, dilute Russell viper venom, and the platelets under test were recalcified and the clotting time recorded.

\section{Results}

Action of Heparin on Christmas Factor.-This was studied using the thromboplastin generation test (Table I, part 1). It may be concluded that heparin in the appropriate strength prevents the formation of thromboplastin but does not inactivate formed thromboplastin, and that heparin in the concentration used does not affect the clotting system in the subsample tubes.

TABLE I

\begin{tabular}{|c|c|c|}
\hline \multicolumn{3}{|c|}{$\begin{array}{l}\text { HEPARIN AND CHRISTMAS FACTOR IN THE } \\
\text { THROMBOPLASTIN GENERATION TEST }\end{array}$} \\
\hline $\begin{array}{l}\text { Dilute Absorbed Plasma and Cephalin in } \\
\text { All Runs and Serum Diluted } 1 \text { in 10: }\end{array}$ & $\underset{\text { (min.)* }}{\text { Time }}$ & $\begin{array}{l}\text { Clotting } \\
\text { Time } \\
\text { (sec.)* }\end{array}$ \\
\hline 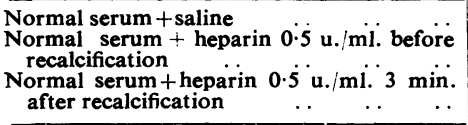 & $\begin{array}{l}3 \\
3\end{array}$ & $\begin{array}{l}11 \\
19\end{array}$ \\
\hline 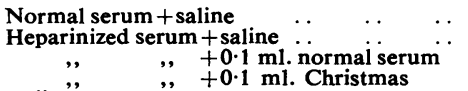 & $\begin{array}{l}3 \\
5 \\
3\end{array}$ & $\begin{array}{r}9 \\
29 \\
9\end{array}$ \\
\hline 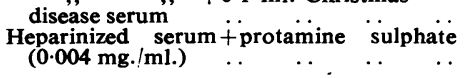 & 4 & 24 \\
\hline
\end{tabular}

*Time elapsed is the time from recalcification till maximal thromboplastin formation is demonstrated by the shortest clotting time in any subsample tube, recorded here as "clotting time." 
The abnormal thromboplastin generation test in the presence of heparin was corrected by the addition of normal serum, but not by an excess of absorbed plasma or Christmas disease serum or by absorbed normal serum. "Heparinized serum" was prepared by letting heparinized blood clot and was shown (vide infra) to contain no available heparin. Its behaviour in the thromboplastin generation test is summarized in Table $I$, part 2. The pre-incubation of heparinized serum with a strong concentration of platelets also revealed C.F. activity (O'Brien, 1959). It is concluded that heparin combines with C.F. and inactivates it. Protamine sulphate and platelet protein remove the heparin from the C.F.-heparin complex to reveal C.F. activity again.

Action of Christmas Factor on Heparin.Christmas-factor-containing and C.F-deficient plasmas and sera were mixed with critical quantities of heparin and the remaining available heparin activity was determined by carrying out thrombin clotting times. Platelet-poor native plasma and "platelet-poor serum" was used (except as indicated); thus the concentration of $\mathrm{Ca}++$ was constant throughout, and any effect due to platelets or P.L.A.S. was excluded. From Table II, $A$ and $B$, it will be seen that the thrombin clotting times of mixtures containing C.F. were shorter

TABLE II

THE INACTIVATION OF HEPARIN BY C.F.

\begin{tabular}{|c|c|c|c|c|c|c|}
\hline & \multirow{3}{*}{$\begin{array}{l}\text { Con- } \\
\text { tains }\end{array}$} & \multicolumn{5}{|c|}{ Thrombin Clotting Time (sec.) } \\
\hline & & \multirow{2}{*}{$\underset{\text { ine }}{+ \text { Sal- }}$} & \multicolumn{4}{|c|}{ Heparin (u./ml.) } \\
\hline & & & $0 \cdot 125$ & $0 \cdot 25$ & $0 \cdot 5$ & 1.0 \\
\hline 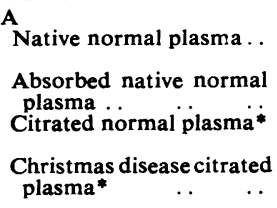 & $\begin{array}{l}\text { Plasma } \\
\text { C.F. } \\
\text { Plasma } \\
\text { C.F. } \\
-\end{array}$ & $\begin{array}{l}24 \\
26 \\
25\end{array}$ & $\begin{array}{l}31 \\
64 \\
50 \\
59\end{array}$ & $\begin{array}{l}42 \\
76 \\
66 \\
80\end{array}$ & & \\
\hline $\begin{array}{l}\text { Bormal serum ... } \\
\text { Absorbed normal serum } \\
\text { Christmas disease } \\
\text { Absorbed Christmas dis- } \\
\text { ease serum .. }\end{array}$ & $\begin{array}{c}\text { Serum } \\
\text { C.F. } \\
- \\
- \\
-\end{array}$ & $\begin{array}{l}16 \\
16 \\
15 \\
15\end{array}$ & & & $\begin{array}{l}16 \\
21 \\
40 \\
39\end{array}$ & $\begin{aligned} & 21 \\
> & 60 \\
> & 60 \\
> & 60\end{aligned}$ \\
\hline $\begin{array}{l}\text { C } \\
\text { Citrated normal serum. . } \\
\text { Normal serum citrated. }\end{array}$ & $\begin{array}{l}\text { C.F. } \\
\text { Ca- } \\
\text { C.F. }\end{array}$ & $\begin{array}{l}20 \\
20\end{array}$ & & $\begin{array}{l}40 \\
24\end{array}$ & $\begin{array}{r}>60 \\
38\end{array}$ & \\
\hline $\begin{array}{c}\text { Citrated Christmas dis- } \\
\text { ease serum } \\
\text { Christmas disease } \\
\text { citrated } . \\
\text { serum } \\
\text {. . }\end{array}$ & - & $\begin{array}{l}20 \\
19\end{array}$ & & $\begin{array}{l}40 \\
40\end{array}$ & $\begin{array}{l}>60 \\
>60\end{array}$ & \\
\hline
\end{tabular}

* These two plasmas were one month old when tested.

One volume of platelet-poor plasma or serum was used throughout and one volume of fibrinogen was added when sera were compared. One volume of saline or heparin in the strength indicated was then added and finally one volume of weak thrombin in $A$ and normal strength thrombin in $\mathrm{B}$ and $\mathrm{C}$, and the clotting time recorded. than those containing none. It may be concluded that plasma C.F. had inactivated some heparin and that serum C.F. inactivated more heparin than plasma C.F. This might be due to the fact that C.F. in serum is a Ca-C.F. complex (Bergsagel, 1955). Normal platelet-poor serum was accordingly decalcified by mixing it with one tenth of its volume of $3.8 \%$ trisodium citrate for 24 hours. This citrated serum was compared with another aliquot of the same serum citrated immediately before testing (Table II C). The decalcified serum apparently inactivated considerably less heparin. Thus the ability of serum C.F. to inactivate more heparin than plasma C.F. is probably related to the fact that serum C.F. is a Ca-C.F. complex.

Serum from platelet-poor Christmas disease blood contains factor VII: absorption of this serum will remove it. Neither of these two kinds of sera inactivated appreciable quantities of heparin. It is concluded that factor VII does not inactivate a demonstrable amount of heparin.

Action of Platelets on Heparin.-Platelet-rich and platelet-poor native plasmas inactivated the same small amount of heparin. Thus intact platelets do not inactivate heparin but fragmented platelets (Table III A) inactivate much heparin. These

TABLE III

INACTIVATION OF HEPARIN BY C.F., PLATELETS, AND P.L.A.S.

\begin{tabular}{|c|c|c|c|c|}
\hline & \multirow{3}{*}{ Contains } & \multicolumn{3}{|c|}{$\begin{array}{l}\text { Thrombin Clotting } \\
\text { Times (sec.) }\end{array}$} \\
\hline & & \multirow[t]{2}{*}{ Saline } & \multicolumn{2}{|c|}{$\begin{array}{l}\text { Heparin } \\
(\mathbf{u} . / \mathrm{ml} .)\end{array}$} \\
\hline & & & 0.25 & 0.5 \\
\hline $\begin{array}{l}\text { A. Citrated platelet-rich plasma } \\
\text { in silicone } \\
\text { Citrated platelet-rich plasma } \\
\text { agitated }\end{array}$ & $\begin{array}{l}\text { Intact } \\
\text { platelets } \\
\text { Platelet } \\
\text { fragments }\end{array}$ & $\begin{array}{l}12 \\
12\end{array}$ & $\begin{array}{l}65 \\
29\end{array}$ & $\begin{array}{l}>60 \\
>60\end{array}$ \\
\hline $\begin{array}{l}\text { B. Normal serum } \\
\text { Platelet-rich absorbed serum } \\
\text { Platelet-poor serum } \\
\text { Platelet-poor absorbed serum }\end{array}$ & $\begin{array}{l}\text { C.F., } \\
\text { P.L.A.S. } \\
\text { P.L.A.S. } \\
\text { C.F. }\end{array}$ & $\begin{array}{l}12 \cdot 5 \\
12 \cdot 5 \\
12 \cdot 5 \\
12 \cdot 5\end{array}$ & $\begin{array}{r}20 \\
22 \\
30 \\
>60\end{array}$ & $\begin{array}{r}24 \\
>60 \\
>60 \\
>60\end{array}$ \\
\hline $\begin{array}{l}\text { C. Citrated normal absorbed } \\
\text { serum } \\
\text { Absorbed normal serum cit- } \\
\text { rated }\end{array}$ & $\begin{array}{l}\text { P.L.A.S., } \\
\text { no Ca } \\
\text { P.L.A.S. }\end{array}$ & $\begin{array}{l}18 \\
18\end{array}$ & $\begin{array}{l}30 \\
24\end{array}$ & $\begin{array}{l}90 \\
50\end{array}$ \\
\hline
\end{tabular}

To one volume of the material in column one was added one volume of saline or heparin in the strength indicated and one volume of fibrinogen. Thrombin was then added and the clotting time in seconds is recorded.

findings are fully compatible with the previous reports of, for example, Wolf (1956) and Rapaport and Ames (1957).

Action of Heparin on Platelets. - The cephalin activity of platelets in platelet-rich plasma was measured in the thrombin generation test. To an aliquot of this plasma was added sufficient 
heparin, e.g., $0.5 \mathrm{unit} / \mathrm{ml}$., together with powdered glass so that the clotting time was not much altered. The thrombin generation curves of the untreated and heparinized samples were closely similar. (With excess heparin, e.g., 1.0 unit, the amount of thrombin generated was less.) The Stypven time of fragmented platelets in plasma was not lengthened by the addition of a moderate excess of heparin. It is concluded that the cephalin activity of platelets is not impaired by heparin. (Yet heparin is inactivated by platelet protein.)

Garrett and Klein (1957) report that the extracted platelet lipid is responsible for thromboplastin formation while the lipid-extracted, watersoluble, presumably protein, moiety exhibits antiheparin activity. Snellman, Sylvén and Julén (1951) point out that heparin and dextran sulphate are attached to lipoproteins not through the phospholipid but that the linkage must be achieved by the polypeptide and may be dipolar in type. It seems therefore that platelet activity in clotting is due to cephalin groups and these are active whether they are "free" or bound to the platelet protein, and that this activity is not influenced by heparin. The protein moiety, whether combined with or freed from cephalin, is responsible for inactivating heparin, the antiheparin effect (see O'Brien, 1958b).

Action of P.L.A.S. on Heparin.-From Table III B it will be seen that serum containing P.L.A.S. (platelet-rich absorbed serum) inactivates more heparin than serum containing no P.L.A.S. (platelet-poor absorbed serum). The long clotting time of recalcified citrated heparinized platelet-

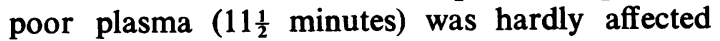
by the addition of absorbed platelet-poor serum

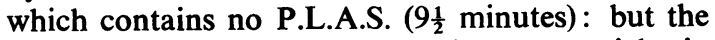
addition of absorbed normal serum rich in P.L.A.S. gave a short clotting time ( $3 \frac{1}{2}$ minutes). It is concluded that P.L.A.S. inactivates much heparin.

The effect of decalcifying P.L.A.S. on its ability to neutralize heparin was tested. Absorbed serum citrated for 24 hours was compared with absorbed serum citrated immediately before testing (Table III C). It is concluded that decalcified P.L.A.S. inactivates less heparin.

Other Coagulation Factors. - The total amount of heparin inactivated by whole blood or by normal serum was almost entirely accounted for by the three interactions reported above; namely, those involving plasma and serum C.F., platelet protein, and P.L.A.S. Thus no other plasma or serum fractions inactivate appreciable amounts of heparin. Conversely it was shown that heparin in appropriate concentration had no apparent effect on the coagulant activity of Hageman factor, antihaemophilic globulin, factor V, factor VII, and platelets.

\section{The Action of Heparin on the Clotting of Whole Blood}

(1) Appearance of Antiheparin Activity during Clotting of Normal Blood.-Two rows of tubes were prepared containing $0.1 \mathrm{ml}$. of two appropriate strengths of heparin, e.g., $0.5 \mathrm{u} . / \mathrm{ml}$. and $0.25 \mathrm{u} . / \mathrm{ml}$. To all tubes was added $0.4 \mathrm{ml}$. of fibrinogen solution. Twenty millilitres of freshly drawn blood was placed in a test tube in the water-bath and allowed to clot and at appropriate intervals $2 \mathrm{ml}$. aliquots were removed, citrated, and centrifuged: one hour later $0.1 \mathrm{ml}$. of each aliquot was transferred to the tubes containing the fibrinogen and heparin and mixed, $0.1 \mathrm{ml}$. of a strong thrombin solution was added, and the clotting times recorded (Table IV). Initially the blood inactivated very little heparin since long thrombin clotting

TABLE IV

APPEARANCE OF ANTIHEPARIN ACTIVITY DURING NORMAL COAGULATION

\begin{tabular}{c|c|c|c}
\hline \multirow{2}{*}{$\begin{array}{c}\text { Time after Taking } \\
\text { Blood (min.) }\end{array}$} & \multicolumn{3}{|c}{ Thrombin Clotting Time in secs. with: } \\
\cline { 2 - 4 } & Heparin (0.4 u.) & Heparin (0.2 u.) & Saline \\
\hline 0 & 67 & 30 & 18 \\
4 & 68 & 32 & \\
7 & 53 & 28 & \\
10 & 60 & 26 & \\
14 & 55 & 24 & \\
$\rightarrow 18$ & 30 & 21 & \\
22 & 24 & 20 & \\
26 & 23 & 20 & \\
40 & 23 & &
\end{tabular}

At the times indicated $2 \mathrm{ml}$. of blood was removed and citrated one hour later $0.1 \mathrm{ml}$. of the centrifuged plasma was added to $0.4 \mathrm{ml}$ of fibrinogen and $0.1 \mathrm{ml}$. of saline or heparin and thrombin added. $\rightarrow$ Indicates first visible clotting.

times were recorded. The ability of the blood to inactivate heparin increased slightly up to the time of the appearance of the first signs of clotting in the blood and thereafter increased rapidly and markedly during the next five minutes.

(2) Disappearance of Heparin Activity during Clotting of Heparinized Blood.-Twenty millilitres of blood from either heparinized volunteers, e.g., 2,000 u. heparin injected i.v. five minutes before bleeding, or normal blood subsequently heparinized, e.g., $0.2 \mathrm{u}$./ $\mathrm{ml}$. blood, was placed in a beaker at $37^{\circ} \mathrm{C}$. and powdered glass added to accelerate the clotting time. The blood usually clotted in about 15 minutes. In each run several of the following tests were carried out on subsamples removed from the beaker at appropriate intervals up to one hour.

(a) Available platelet cephalin was monitored up to the time of clotting only (thereafter the platelets are largely caught up in the clot) by serially removing 
$1 \mathrm{ml}$. subsamples from the beaker, citrating, and estimating the Stypven time one hour later. This test was shown to be unaffected by the concentration of free heparin present.

(b1) Thrombin formation was monitored by subsampling $0.1 \mathrm{ml}$. amounts into $0.4 \mathrm{ml}$. of fibrinogen solution.

(b2) Thrombin generation could also be indirectly studied by doing two-stage prothrombin tests on the citrated subsamples of the blood one hour later.

(c) The Formation of P.L.A.S.-Amounts, each of $1 \mathrm{ml}$., were removed and citrated. They were centrifuged and (usually) absorbed to remove platelet activity and any free heparin, and one hour later they were tested for P.L.A.S. as previously described.

(d1) The neutralization of heparin by the blood in the beaker was monitored by subsampling into a fibrinogen solution, adding a strong solution of thrombin and estimating the thrombin clotting time.

(d2) The neutralization of heparin was further studied by estimating the clotting time of plateletpoor citrated normal plasma to which was added hour-old citrated subsamples of the blood from the beaker.

Similar appropriate observations were carried out on unheparinized blood.

\section{Results}

The rate of formation and the approximate concentrations of platelet cephalin, of thrombin, and of P.L.A.S. were not appreciably influenced by the initial presence of heparin in the blood (Fig. 1). Prothrombin was completely consumed 10 minutes after clotting. Tests $(d 1)$ and $(d 2)$ revealed an initial slow fall and then a rapid fall and complete disappearance of "available heparin " about the time visible clotting occurred. Indeed, apart from some variation in the time scale, the heparinized blood gave, along the parameters studied, similar results to those of normal blood. When 1 unit of heparin per $\mathrm{ml}$. was added to blood the clotting time was lengthened from 10 minutes to four hours. If powdered glass was added the clotting time was still somewhat prolonged and no thrombin generation could be demonstrated (it was probably formed too slowly), but prothrombin consumption was complete 15 minutes after clotting and available heparin disappeared. When sufficient heparin was added to render the blood incoagulable for 24 hours apparently all the heparin remained available at this time.

It is concluded that a moderate dose of heparin delays clotting by its action on C.F. The subsequent steps in the coagulation process are little altered; in particular thrombin generation is normal. This must be due to the absence of "available" heparin at this time. Before fibrin forms, some heparin is presumably inactivated by plasma C.F. and the increasingly available platelet protein. The sudden disappearance of all heparin activity is presumably due to the formation of serum C.F. and P.L.A.S., both of which inactivate much heparin.

The Nature and Significance of P.L.A.S.-The preceding experiments have demonstrated some properties of P.L.A.S.: its origin and nature and function will now be briefly considered (Table V). It is formed during clotting only if platelets are

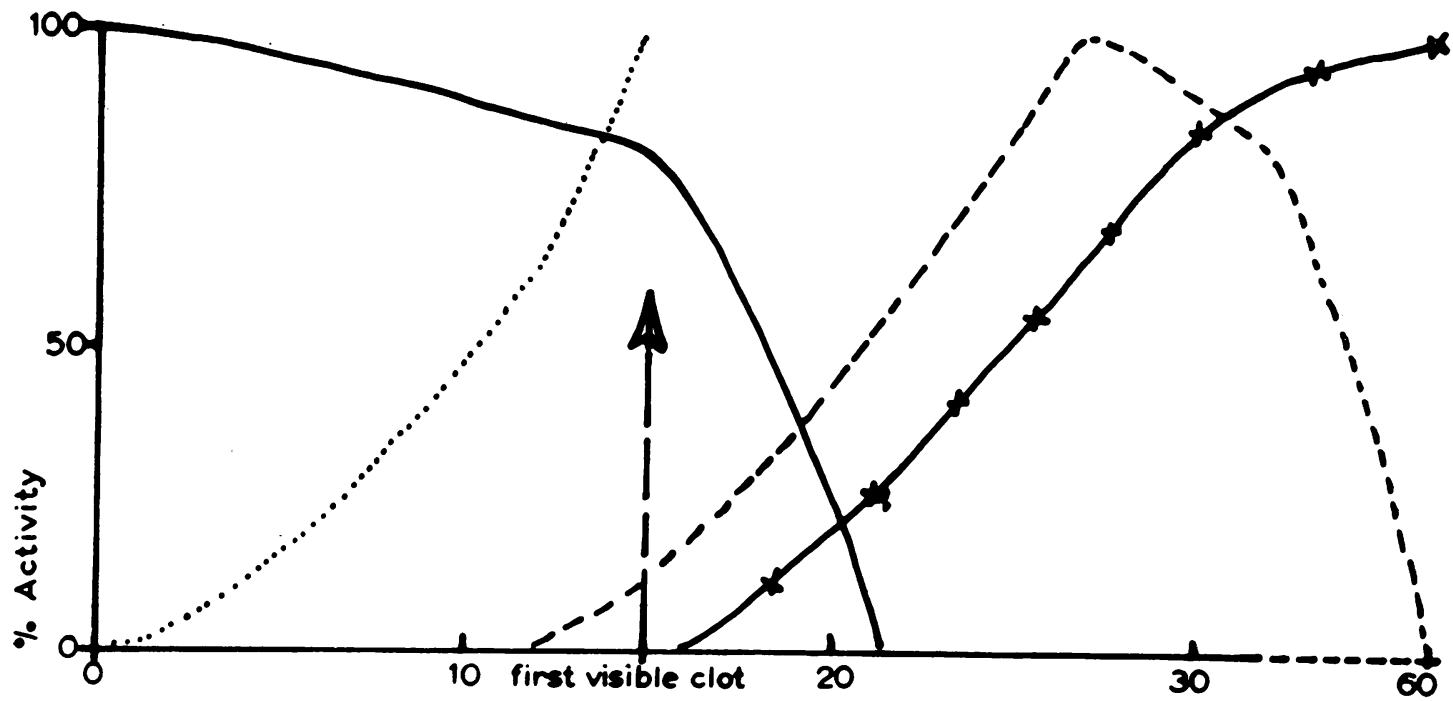

FIG. 1.-The activity level of some coagulation factors and available heparin during the clotting of heparinized blood. Platelet cephalin . . . . thrombin - - - , P.L.A.S. $\mathbf{X}-\mathbf{X}-\mathbf{X}$, available heparin - 
TABLE V

SOME PHYSICOCHEMICAL AND COAGULATION PROPERTIES OF P.L.A.S. AND PLATELETS COMPARED

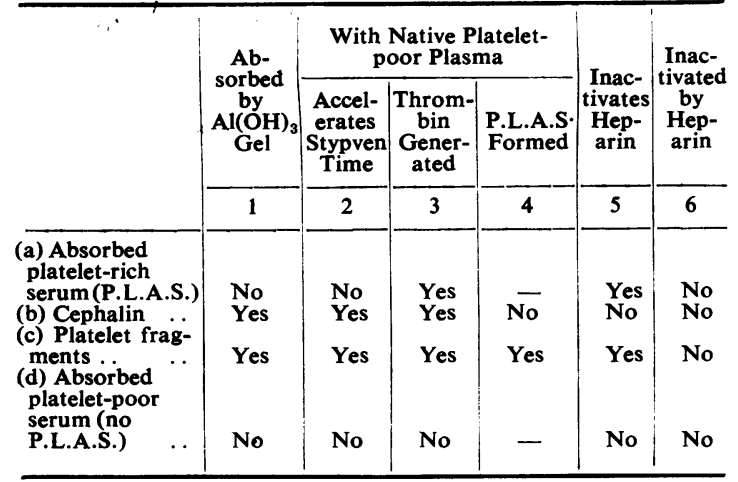

present: when added to plasma it has the same effect as platelets in permitting thrombin formation: and, like platelet protein, it inactivates heparin. It is thus likely, at least in part, to be derived from platelets. Unlike platelets it is not absorbed by aluminium hydroxide gel and it does not accelerate the Stypven time. Platelet-like activity of serum therefore almost certainly has no available cephalin groups, and it is soluble, and yet it permits thrombin generation. Plateletlike activity of serum may be a degradation product of platelets after they have exerted their activity in the clotting processes. The evidence is also compatible with the concept that the platelet protein-cephalin complex is altered to P.L.A.S. with the loss of "available cephalin" groups and that P.L.A.S. then plays an essential part in blood coagulation.

Relative Ability of Some Proteins to Bind Heparin.-Platelet protein, P.L.A.S., and C.F. appear to be unique among all the plasma and serum proteins in their ability to bind heparin strongly. It is remarkable that only coagulation factors should have this attribute. Since these three proteins uniquely share this property it is probable that some part of their molecular structure must also be similar; P.L.A.S. and serum C.F. are probably combined with calcium and all three may contain lipid (O'Brien, 1956, and unpublished work). At present there is no further information.

The results of the foregoing experiments can also be considered from the point of view of the relative ability of the various coagulation factors to bind heparin. Heparin in small quantities added to plasma is bound largely by the $\beta$ lipoproteins (Bernfeld, Donahue, and Berkowitz, 1957; Nikkilä, 1953), yet this heparin is " available" to delay the thrombin clotting system. This latter system must have a greater affinity for heparin than the $\beta$ lipoproteins. Conversely, heparin bound to C.F. does not influence the thrombin clotting system. The affinity of heparin for C.F. must be greater than its affinity for the relevant protein involved in the thrombin clotting system. The addition of platelet protein to the heparin-C.F. complex liberates C.F. activity, indicating that the affinity of heparin for platelets is greater than that for C.F. And the ability of protamine sulphate to reverse the heparin effect on all these factors indicates that the attraction between heparin and protamine sulphate is greatest of all. This conclusion may be expressed diagrammatically:

\section{Increasing Affinity for Heparin}

$\beta$ Lipoprotein $<\underset{\text { System }}{\text { Thrombin }}<$ C.F. $<$ Protein $<$ Sulphate

My thanks are due to Mrs. J. Cheater, A.I.M.L.T., for excellent technical assistance. This work was carried out during the tenure of a grant from the Medical Research Council for technical assistance which I gratefully acknowledge.

\section{Addendum}

Since the preparation of this article, Grieg (Brit. med. J., 1959, 2, 25) has reported that he can confirm the basic experiments with heparin and C.F. reported here and elsewhere (O'Brien, 1958a).

\section{REFERENCES}

Bergsagel, D. E. (1955). Brit. J. Haemat., 1, 199

Bernfeld, P. Donahue, V. M., and Berkowitz, M. E. (1957). J. biol. Chem., 226, 51 .

Biggs, R., and Douglas, A. S. (1953). J. clin. Path., 6, 23

- Macfarlane, R. G. (1953). J. Physiol. (Lond.), 122, 554

Creveld, S. van, and Paulssen, M. M. P. (1951). Lancet, 2, 242.

Douglas, A. S. (1956). J. clin. Invest., 35, 533.

Garrett, J. V., and Klein, E. (1957). Proc. Soc. exp. Biol. (N.Y.), 96, 823

Hougie, C. (1958). Ibid., 98, 130.

McGovern, V. J. (1955). J. Path. Bact., 69, 283.

Nikkilä, E. (1953). Scand. J. clin. Lab. Invest., 5, Suppl. 8.

O'Brien, J. R. (1955). Brit. J. Haemat., 1, 223.

- (1956). Ibid., 2, 430.

(1958a). Nature (Lond.), 181, 1801

- (1958b). Ibid., 181, 420 .

Rapaport, S. I., and Ames, S. B. (1957). Proc. Soc. exp. Biol. (N.Y.) of, is8.

Shanberge, J. N., Barlas, A., and Regan, E. E. (1958). J. Lab. clin. Med., $52,744$.

Snellman, O., Sylvén, B., and Julén, G. (1951). Biochim. Biophys. Acta, 7,98

Walton, K. W. (1955). Brit. med. Bull.,11, 62.

Wolf, P. (1956). Brit. J. Haemat., 2, 375. 